\title{
Balkanologie
}

Balkanologie Revue d'études pluridisciplinaires

Vol. II, nº 2 | 1998

Volume II Numéro 2

\section{Too Much Character, Too Little Kultur : Serbian Jeremiads 1994-1995}

\section{Marko Živković}

\section{(2) OpenEdition \\ 1 Journals}

\section{Electronic version}

URL: http://journals.openedition.org/balkanologie/263

DOI: 10.4000/balkanologie.263

ISSN: 1965-0582

\section{Publisher}

Association française d'études sur les Balkans (Afebalk)

\section{Printed version}

Date of publication: 1 December 1998

ISSN: 1279-7952

\section{Electronic reference}

Marko Živković, "Too Much Character, Too Little Kultur : Serbian Jeremiads 1994-1995 », Balkanologie [Online], Vol. II, n² 2 | 1998, Online since 02 June 2008, connection on 17 December 2020. URL : http:// journals.openedition.org/balkanologie/263; DOI : https://doi.org/10.4000/balkanologie.263

This text was automatically generated on 17 December 2020.

(c) Tous droits réservés 


\title{
Too Much Character, Too Little Kultur : Serbian Jeremiads 1994-1995
}

\author{
Marko Živković
}

\author{
Culture without character is, no doubt, \\ something frivolous, vain, and weak ; but \\ character without culture is, on the other hand, \\ something raw, blind, and dangerous. ${ }^{1}$
}

1 At the televised July 1994 session of the Serbian Parliament debating the issue of the control over the regime-run TV, a respected singer of Medieval Serbian spiritual music, Pavle Aksentijević, acting as a member of the largest opposition coalition (DEPOS), brought a tape recorder to the podium and played a tape of a contemporary Iranian popular song. Then he played a song by Dragana Mirković - one of the most popular female singers of the so-called "turbo-folk" genre. The tunes were practically identical. He ended his performance by quoting a prominent Yugoslav historian Vladimir Dedijer : "we Serbs sometimes behave as if we were made ["begotten"] by drunken Turks».

2 Among the intellectual circles in Serbia, a conspiracy theory had been circulating for some time that the flood of "turbo-folk" unleashed in the last few years was a cunning plot devised by "Them" (Milošević, the Socialist Party, the authorities) intended to reduce the population to utter idiocy ${ }^{2}$. At one level, then, Aksentijević was accusing the regime of promoting an abominable genre of kitsch, primitivity and unculturedness. His performance, however, added the theme of Oriental, or more specifically, Turkish taintedness ${ }^{3}$. He was accusing the establishment of deliberately polluting "Serbdom" with Oriental tunes, and simultaneously positioning himself and his party as defenders of a certain kind of pristine Serbian culture.

3 Labels like "culture" could be likened to empty thrones, wrote Edward Sapir: " the rival pretenders war to death; the thrones to which they aspire remain splendid in gold $»^{4}$. Like Sapir, Aksentijević was advancing the claims of a particular pretender to the empty throne of culture, and implicit in this move was a claim to cultural supremacy over the ruling Socialist party. His performance was perhaps most 
significantly a claim to authentic nationalism of his own party as opposed to the false nationalism of Milošević ${ }^{5}$. Far more than just an argument over the musical taste, this constituted a claim to power.

In some other context, this might have been a powerful rhetorical move, but not in the totally marginalized Serbian Parliament that people almost universally considered a "circus". The ruling party held it up to the international community as a proof of its "democracy", while the domestic public was treated to a spectacle of opposition's utter futility. And just like in the circus, the audience was laughing at the clowns: while Aksentijević was playing his tapes, the (in)famous Bidža of the ruling Socialist Party - a local despot of the Svilajnac municipality and a fat, bald, boar-like incarnation of selfsatisfied vulgarity - was mocking his efforts by making a show of swaying to the music in the Oriental fashion and clapping his hands with a beatific expression on his face as if to say - yes, this is exactly the music we, "the people" like the most - thus sending the populist message to the TV audience : let the pretentious intellectuals rant and rave, we (the Socialists) are not ashamed of the music that the people obviously love. One social commentator observed how behavior like Bidža's serves to impress the people with the power of the ruling party. The contempt of the opposition and arrogance thus shown, he argued, " press the right buttons with the people accustomed to docility due to the proverbial five centuries of the "Turkish Yoke" ${ }^{6}$. Most importantly, it was the "uncultured" who were arrogantly showing their contempt towards the "cultured" and thus, in the perception of the "cultured", turning the normal scale of values upside down.

5 The sentence with which Aksentijević concluded his performance does much more than accuse the regime of polluting Serbdom with Oriental kitsch. Deep anguish is coming out of that statement - it might be construed as saying that we [Serbs] must all be deeply faulted if we are letting all of this happen : if we are letting Bidža and his likes rule over us, if we let them ruin us with war and sanctions, and if after all of that we are still keeping them in power. When it comes to expressing such deep selfrecrimination, nothing in Serbian repertory of themes could be as powerful as the entangled complex of the Turkish Taint. Aksentijević was not only making a statement on culture but on the national character as well. It was as if he was saying: "we are products of violence and rape ; we were made by the hated Orientals, and not even by the Turks at their best, but by the drunken Turkish rabble; thus we are half-breeds, mongrels and bastards, and even though we utterly resent it, we really are like Turks at their very worst ${ }^{7}$.

6 Exactly at the time of that Parliament session, the Bosnian drama was reaching yet another peak. When the Government of Republika Srpska refused to accept the Contact Group Peace Plan, the Federal Republic of Yugoslavia (Serbia and Montenegro) accused it of « the greatest treason of the Serbian national interest that has ever occurred » and imposed what then seemed a total blockade upon their brothers across the Drina river. A major "surrogate" of the Milošević regime - Radovan Karadžić - was thus cut loose, and the media campaign was unleashed with the aim of transforming him from a hero to a villain, from a noble fighter for the just Serbian cause to a gambler, war profiteer, even a war criminal.

7 Overnight, the state-run TV changed its tune completely. «Peace has no alternative » was the new slogan, and for weeks, an endless procession of people, from passers-by on the streets, to company directors and politicians, parroted it on the TV screen in 
complete contradiction to what they were saying only a day before. Yet even though the regime's ideological and policy shifts promoted through a succession of "surrogates" had already exposed the Serbian public to a benumbing number of cognitive/moral "warps" this latest one was arguably the most vertiginous yet.

8 The people remained "docile" as ever, and the oppositional intelligentsia increasingly turned to laments that shuttled back and forth between "our lack of culture » and " the faults of our national character ». These "Jeremiads", as I want to call them, are a variant of what N. Ries called " litanies and laments » in the context of the post-Soviet Russia9. I will focus on the period between August of 1994 and August of 1995, because it is in that period that Serbian Jeremiads seemed to reach their "purest" form and became a ubiquitous, if not a dominant genre of social commentary that ranged from everyday talk to discourses of social scientists. Moreover, it is during that period that the Milošević regime makes a 180 degree turn that appropriates, preempts and "colonizes" the rhetorics and initiatives of the opposition Jeremiads by "simulating" 10 their cultural criticism. Finally, in contrast to the previous few years of nationalist euphoria, the talk about national character started to focus increasingly on the flip-side of the heroic Dinaric type - the fawning servility of the rayah mentality. It is this turn that better illuminates the whole complex of the Dinaric mentality - the mainstay of discourses on the national character in Serbia since ethnogeographer Jovan Cvijić first formulated it at the turn of the century ${ }^{11}$.

If the genre of everyday "sifting of politics" (bistriti politiku) usually relies on conspiracy theories ranging from local context to vast conspiracies incongruously involving Vatican, Comintern and the New World Order, the Jeremiads sought the reasons for the present Serbian predicaments in "deeper" causes having to do with fatal flaws in Serbian culture and character. Super-charged with a kind of Bakhtinian «internal dialogism ", the terms culture and character tend to accumulate the "taste " of numerous past and present contexts in which particular social groups imbued them with their "socially significant world views $»^{12}$. Thus Serbian Jeremiads of 1994-1995 can offer a valuable insight into the social tensions and political agendas struggling for supremacy in Milošević's Serbia.

\section{The First Jeremiad : Communist Legacy and the Moral Breakdown of the Serbian People}

On August 21, 1994, right after Milošević's turn from warmongering to peacemongering, the popular TV show Impression of the week had Dragutin Gostuski, a renowned musicologist and highly respected culture-critic as one of the three guests in the studio. Asked by the hostess what he remembered as the strongest impression of the previous week, he launched into a classical Jeremiad underlined by the look of deep depression on his face, and the leaden tone of his voice punctuated with long sighs and silences of a deeply troubled man (marked by ellipses in my transcription) : "You know, the impression that I am carrying from this week, from these last weeks, unfortunately is the same impression that I have been carrying for exactly fifty years ... And that is a heavy impression ... bad ... the moral breakdown of the Serbian people ...) ». Gostuski's deep anguish is obviously occasioned by the latest evidence of how his people easily bend, and change overnight what should have been deep convictions under the pressure of an authoritarian regime. For him it bespoke of a tragic lack of 
moral fiber, of integrity and backbone. «For, you see, the moral breakdown is something terrible ... heavy ... something with huge consequences. You could change the political system, you could regain lost territories, but a loss of morality, that is a thing which affects the human soul so deeply, that it could not be rectified even in a hundred years ». And he immediately associated this most recent event with the situation in 1945, after the Communist takeover. «I was surprised ... by the extent to which our people suddenly changed their opinion, under various pressures, to be sure, but also often without any need. How treason, cowardice, sycophancy, falsehood, and deceit started to appear, mass joining of the Communist party by people who never thought they would turn into Communists, and who calculated it to be a good move bringing some social privileges and a better life ... ». Such lack of backbone does not agree with the entrenched self-image of Serbs as heroic, independent, and proud people and Gostuski now starts to doubt even the most hallowed instances of Serbian heroism. " ... I wondered how could a people who makes so much of its heroism, its courage and honor, who proved through history ... I started to doubt, I am telling you sincerely, I started to doubt even the Kosovo battle, even the Salonika front, and all these heroic and honorable deeds of the Serbian people and I asked myself how could something like this happen ...». And he offers a quite wide-spread thesis as an explanation :

I pretty much tend towards a thesis, supported in particular by our writer Danko Popović, that the Serbian people has not, in fact, recovered ... biologically ... from its losses in wars. Terrible losses in the First World War and in the Balkan War ... and then it was (sigh) ... finished in this war ... when it happened that ... as everybody knows, in the war only the bravest, that is to say, also the most honorable men get killed. (...) So that, it is not too far fetched to conclude that with this damage we have become, in the majority, a genetic trash, because those who remained were mostly deserters and dodgers, and people of bad character, and that, of course, through generations has been reproduced.

11 Two significant threads could be followed from Gostuski's statements. The first is to blame fifty years of Communism for having broken the moral backbone of Serbs. This is a complaint often made, and it is probably familiar in most post-communist societies. A prominent writer and social commentator, Milovan Danojlić, however, offered a penetrating analysis of how Tito's special brand of Communism, with its anti-Soviet rhetorics, open borders, seeming freedoms and a higher living standard, might have corrupted the Yugoslavs in a way even more devious and sinister than the Soviet type of real socialism : "we lived in bearable evil », he wrote, " it devastates the soul worse than tyranny $»^{13}$. But if fifty years of Communism had broken the Serbian moral backbone, a further question can be asked of why did the Serbs succumb to Communism in the first place, and why are they still supporting another neocommunist one - Milošević's. While Gostuski and Danko Popović adhere to the popular thesis of genetic thinning out, especially after the turn of 1994, the answer to that question came to be increasingly sought in the proverbial five centuries of Ottoman rule. As an aphorism put it : «the Communist didn't pick the Serbs for nothing. Five centuries under the Turks are our best recommendation $»^{14}$.

" On our soil, after many centuries of slavery under the Turkish yoke and after many decades of communist rule ", writes an expert on ethnopsychology, Žarko Trebješanin,

a special type of authoritarian-submissive personality developed as one possible human response to brutal, inhuman living conditions. The authoritarian-submissive personality system represents a specific hybrid of authoritarian consciousness and 
"rayah mentality" (Cvijić), characterized by: worship of authorities, pragmatism, egoism, submissiveness, servility, resentment, and moral mimicry ${ }^{15}$. the Drina river, it is only to be expected that the latter might have a different view of the situation. In 1991, the influential Belgrade weekly NIN was running a series of essays titled : "The Dinarics and the Serbians » (Dinarci i Srbijanci). The fifth installment of May 17, features Nikola Koljević, a professor of English literature at the University of Sarajevo and later one of the top leaders of Republika Srpska. He accuses NIN (as a newly "liberated" seat of urban liberal opposition ${ }^{18}$ ), of discrimination against the Dinarics. They got the worst deal in NIN's " anthropogeographical meditations » on « who is who » in Serbia, Koljević writes sarcastically,

First because they were the ones who refused to be cast in chains preferring instead to be in a centuries long mountain hideaway, guilty because they settled the more fertile and richer regions. Guilty of thinking that Serbia is a free country for the Serbs born outside of it as well.

Their other, and much graver sin is that ... they have taken over many respectable and influential positions. They have established their own networks ... and the Belgrade lobby simply cannot stand that any more.

Neither is it "civilizationally" correct. How could it be when, since the times of Cvijić, it is well known that those are one and all violent types who are poisoning the agrarian tender souls with their aggressive visions of Serbian unity and concern for the brothers in other Serbian regions.

This diatribe is full of allusions that might be profitably unpacked in some other context, but suffice it to notice here how the «agrarian tender souls » are put in the 
same category with "decadent" Belgrade elite luxuriating in fine distinctions, high falutin democratic principles and neurotic individualism at the time when the great danger to the nation as a whole necessitates the highlanders' superior mettle and sense of national mission.

Koljević here turns the tables on the Belgrade opposition circles who claim a longstanding anti-communist and bourgeois ${ }^{19}$ pedigree. These circles are very fond of pointing out how the new Communist elite which flooded Serbia after the WW II, disinherited the old bourgeois elite and purged them physically, was overwhelmingly composed of the highlander Dinarics from outside of Serbia proper. Now here's a response from the viewpoint of "agrarian tender souls", comming from Nikola J. Novaković, a lawyer from Novi Sad, and secretary of the local Rotary Club :

Our Djole Nacionale ${ }^{20}$ is wrong when he says that Novi Sad is peasantified (poseljačen). If only we were that lucky! Our peasants lean on the Fruška gora ${ }^{21}$ with their feet in the Danube, and they see to the ends of Europe. Those others [highlander newcomers] do not have the breadth [of view] and do not know how to look. When you show them the horizon of our flat land they say: "You are fucking with me, can't you see that nothing could be seen!" These people are used to the near and to see nothing but the mountains up to their noses, only the sky, vertically ... Some hard people and harsh. [They] holler and snarl, swallow vowels or twist them. They proclaimed force and power for justice, deception and corruption for morality, malice and envy for customs, Asiatic howling for music, and pistols and revolvers for national costume ... Comrades ${ }^{22}$, here we celebrate others' successes and we pay for our own drink. This is the essential difference between the comrades and the gentlemen (gospoda). I am not losing hope that you will understand the importance of good manners and home upbringing ${ }^{23}$.

Not having mountains to block his view, the Vojvodina lowlander peasant can see to the ends of Europe, he is thus allied with it, as with civilization and culture. In Novakovićs view, he is a kind of peasant-cosmopolitan ${ }^{24}$. And for all the bitterness the natives feel for newcomers, according to the saying: " came the wild, kicked out the tame» (došli divlji, oterali pitome), Novaković believes that the "wild" will eventually be tamed.

Depending of who is talking to whom, when, under what circumstances, and for what purpose, the permutations and combinations, sometimes seemingly logically inconsistent, of these ethnopsychological distinctions can assume dizzying complexity. The tokens of highlander or lowlander mentality could be pinned on different regions, and different groups of people in order to " exalt or debase identities » in the "quality space $»^{25}$. They could be and often are used in the way Gal calls "recursive", as shifters, or fractally in the sense that the labeling tends to get reproduced on ever smaller scales $^{26}$. Moreover, the rival groups (in particular the "Serbs" and "Serbians") tend to analyze the supposed Communist mentality (a negative characteristic in most oppositionary rhetorics) of their opponents in terms of their highlander or lowlander traits.

21 These character types, however, are often used without geographic localization in order to talk about the general Serbian character. In that sense, the Dinaric character and Rayah mentality could be seen not as characterizing different populations, but as being two sides of the same coin, or two phases of the same character structure, in a way, for instance, that mania and depression could be just different phases of the maniacal-depressive disorder. The analogy is not spurious, for psychiatric diagnoses of 
the national character became a prominent type of stories Serbs told themselves about themselves in the last few years.

\section{The Second Serbian Jeremiad : Is Homo Balcanicus (still) a Homo Heroicus, or just an Adolescent Braggart?}

At the book promotion of literary critic Petar Džadžić's two volume work on ethnopsychological themes ${ }^{27}$ (June 6,1995 ) an eminent Jungian psychiatrist, Vladeta Jerotić ${ }^{28}$, compared the Balkan Dinaric type with an average adolescent :

Inclined to strong imagination, his emotional life at odds with thinking, at times omnipotent ... at times dejected, as if he's lost everything, the Balkan Dinaric does not judge reality well precisely because of these traits of temperament and character. ... It is impossible not to notice a similarity between the behavior of the Serbian Dinaric and the behavior of an average adolescent.

Here the national character embraces both the rayah moral mimicry and the megalomaniac Dinaric heroism united in a Balkan "homo duplex". To liken national character to that of an adolescent is like comparing those lacking culture or civilization with children, lunatics, women, and with nature. In that sense Jerotić's judgment would put the Serbs somewhere in-between - as an adolescent is half-way between the child and the adult, so is the Balkan man half-way between barbarity and civilization, nature and culture, tradition and modernity, raw and cooked. Indeed, one might say, he is half-baked, neither here nor there, he needs finishing, polishing, refinement, maturing, cultivation. As Arnold had put it: « ... character without culture is something raw, blind, and dangerous ».

There was a general feeling at that book promotion, certainly reinforced by recent events, that something essential and very important is lacking from the national character. It was Ratko Božović, a sociologist of culture and prominent culture-critic (himself of Dinaric descent) who explicitly talked about that lack, as the lack of a "cultural model" (kulturni obrazac) by invoking a famous essay on Serbian national character by Slobodan Jovanović, one of the most influential intellectual and political figures in recent Serbian history.

Serbs have developed both the political and the national models, Jovanović was saying, but they lack a cultural one. He was talking about culture in the sense of self-perfection of the individual, the harmonious and comprehensive development of the person, that is to say in the sense of bildung. What he had in mind was a cultural model concerned not with "perfecting the social institutions, but with cultivating the individual, such as, for example, the "model built by the old humanists on the basis of ancient philosophy", or the English "gentleman", the German "cultured man", and the French "honnête homme" $»^{29}$. The cultural model is, however, developed by the older, or more fortunate nations, rather than the individuals, and should be emulated by the nations that lack it.

"Culture", that refinement that we need in order to rectify our half-baked or « raw, blind and dangerous » character has to be imported from places that have already developed it, and models, are, as L. Greenfeld would say ${ }^{30}$, by definition superior to model imitators. Emulation brings resentment and attempts to transform one's faults 
into virtues, and other's virtues into vices. Thus our (German) Kultur, or our (Russian) Soul is superior to your (French) civilization, or your (Anglo-Saxon) soulless mercantilism.

Some among the Serbian elites, like Slobodan Jovanović, wholeheartedly embraced imported Western models. Those, however, who resented them have shown two types of analytically distinguishable responses: one that lays claim to the Byzantine High Culture heritage of the Serbs presented in its positive valence, as a civilization and culture superior to that of the West (in the West, of course, the very word "Byzantine" carries all kinds of Orientalist taints) ; the other extols the native "barbarogenius" - the innate superiority over the West of the Serbian peasant Volkgeist. In practice, the two are mostly amalgamated and mixed in various proportions and permutations, but sometimes they come to be distinguished and even opposed to each other ${ }^{31}$.

Both Božović and Jovanović, constantly conflated several important senses of the term "culture". One is "culture" as bildung, - personal refinement and perfection. Another is "culture" as a marker of social "distinction" in Bourdieu's sense. In yet another sense, "culture" stands for the collective, national genius in its various guises. The story of how Kultur as a weapon of inter-class distinction in Germany was transformed into the inter-national distinction between French civilization and German Kultur is one of the founding stories of modernity ${ }^{32}$, and the two axes of comparison have been conflated ever since. Once nationalised, culture became democratized, then massified, and mechanically reproduced thus causing the cultural angst of a new breed of cultural critics from Simmel, through Benjamin to Sapir and Adorno. Through all these historical accretions, the notion of "culture" assumed the polyvalent richness that made it into an extremely potent multi-purpose weapon in all kinds of social struggles. It became heavily contentious and emotion-laden. When I approached Ratko Božović after the book promotion and asked him what exactly did he mean by "cultural model", he became highly agitated and almost shouted at me : « what do I mean? What do you mean I mean by culture? - sensibility, intellectuality, morality ... sense of responsibility!» "that's what we lack!». And then with a pained expression of revulsion mixed with indulgence towards the character flaws of his own people he abruptly turned and left.

We might lack culture as something that would tame, polish and complete our unruly character, the panelists were all saying, but they probably didn't mean that the whole of the nation equally suffers from «too much character and too little Kultur»; not all Serbs lack culture, and those who actually do have it, should reform, educate and cultivate, that is to say, lead those who do not. The "cultured", however, were not leading the "uncultured" in Miloševićs Serbia. As another Jeremiad had put it, «the wise got silenced, the fools climbed into the saddle, and the rabble got rich». The Serbian Jeremiads of mid-nineties were comming from marginalized intellectual elites, ignored, or at most used as disposable "surrogates" by the regime.

\section{Culture as Self-Defense of Society and Personality : The Riders of the Cultural Apocalypse}

30 Some three months before that book promotion, the marginalized and besieged oppositional intelligentsia gathered for a conference titled Culture as Self-Defense of Society and Personality ${ }^{33}$, where for two days they engaged in agonized denunciations of 
what Ratko Božović, who again was one of participants, termed «the Riders of the Cultural Apocalypse » :

It is noticeable that in the capital city there is no more middle stratum. It plunged into the chasm of poverty. There's no possibility that it can reproduce any elite. The elite is now determined by wealth and property, not by spiritual superiority. And without the elite of spirit and of knowledge there is no entrance into the $21^{\text {st }}$ century.

From the half-world of the [criminal] underground, from the provincial suburbs, from the twilight of metropolis, from the hell of war - there emerged the riders of the cultural apocalypse. More precisely: the white collar criminals, the hard currency rentiers, the war profiteers and the dangerous, criminal types - the mafiosi. More or less everything that was objectionable in spiritual and moral terms appeared at the very center of the degraded reality. Like some formless and terrifying shadows, the new primitives accompany the times of crisis, anxiety, fear and emptiness. There, one can begin the story of their spiritual poverty, of the nature of their raw strength which is far from either culture or cultivation, removed both from emancipation and education. One could actually end that story on the note about the vitality of primitivism, bolstered by the zurle i talambaši ${ }^{34}$ of the newly composed (novokomponovana) culture were it not for the fact that the folkloric spirit and the neorural primitivity have nested in the urban environments as well. Our aesthetician Dragutin Gostuski was surprised by the extent to which the scale of values had been degraded, and especially by the tendency of the urban youth to fall into the embrace of primitive and Islamicized music and abandon the "international pop sphere".

It makes almost no sense to discuss the easily recognizable "axiology" of the world that feels at home in the junkyard of kitsch. The nouveau riche take all that life offers, all they can grab ... These fishers in troubled water (mutnolovci) - foreigners to intellectuality, sensibility and morality, and very close to the aesthetic of kitsch achieved the strategy of winning important positions in the society... Immoderation, bad taste, grandomania and arrogance are marks of their life style. A style without style. The refinement of the newly composed rich is laughable and caricatural. Full pockets, empty souls.

31 It is clear that, in Bourdieuan terms, Božović is here engaging in a classification struggle, a game of cultural one-upmanship predisposed, like all talk of art and cultural consumption, «to fulfill a social function of legitimating social difference ${ }^{35}$. He is certainly trying to put himself in the place of «cultural nobility» by denouncing the "undifferentiated hordes indifferent to difference ${ }^{36}$. The impression one gets from reading Bourdieu is of an almost crystalline structure of minute distinctions within which is waged a lively but highly ordered classification struggle. No sense there that every so often come catastrophe totally erases these distinctions and the very classes engaged in the struggle.

Even though engaged in the distinction game in its fundamental logic similar to the one Bourdieu uncovers in France, the Serbian intellectuals, however, often view the very structuration, that is, the differentiation and hierarchization of their society as something very recent, undeveloped and precarious ${ }^{37}$. It is moreover, subject to tragically frequent disasters that level the painstakingly built differentiation or completely reverse it when, according to the above mentioned formula, «the wise get silenced, the fools climb into the saddle, and the rabble gets rich ".

This is what Božović points to when he talks about the middle class being plunged into the chasm of poverty and unable to produce the social elite. Perhaps the clearest and most succinct statement of this problem comes from another participant in the 
Conference, the urban sociologist Sreten Vujović, and it is worth quoting at some length :

Urban development and the bourgeoisie have been experiencing tragic discontinuities in our regions ${ }^{38}$, the bourgeoisie had been few, short lived, and powerless, and to this day has not been able to impose itself as an agent of any kind of significant social change.

In our society, as a distant province and a semi-colony of the Ottoman Oriental despoty, the bourgeoisie and enterpreneurship, as the carriers of the liberal orientation, could not have developed and entrenched themselves properly. The social structure didn't change much even after the "peasant-bourgeois" revolution ${ }^{39}$. Instead of the bourgeoisie (gradjanstvo) the ruling stratum was the trading bourgeoisie of peasant origin whose cultural-ethical and political value orientations were not a milieu particularly advantageous for the economic and political modernization. In the whirlwinds of the Balkan, the First and the Second World wars, as well as in the first years after the Second World War, the already scarce bourgeoisie was significantly reduced in number. Oriented towards the autocratic state and very much dependent on it, the thin stratum of the bourgeoisie mostly did not incline towards liberal ideas. The dissident, that is to say, the oppositionary groups which were more or less publicly active after 1945, were most often of Marxist orientation, and that meant they were either against or ambivalent towards the bourgeoisie.

In a word, at the time of the uprisings, which is the time of its "birth", the Serbian society starts out as a remarkably "flat", undifferentiated society composed of peasants only, and in the next 200 years whatever social differentiation develops it gets repeatedly "flattened" again in a series of wars and other catastrophes. This, according to Latinka Perović ${ }^{40}$, is the social foundation for what she claims is the most enduring and influential Serbian ideology that could be summarized in the saying: «I don't care how little I have as long as my neighbor doesn't have too much more », that is, the ideology of the lowest common denominator, egalitarianism in poverty, antiliberalism, anti-capitalism, in a word, anti-differentiation.

Those who aspire to cultural nobility have always denounced the parvenus, the arrivistes, the nouveau riche, or the philistines in more or less the same terms Božović uses - for their "raw strength" bereft of "culture or cultivation", for their "spiritual poverty", their "immoderation", "bad taste", "arrogance", or "empty souls". What makes a Jeremiad like his, and the chorus of Jeremiads heard at the Conference so rich and revealing are the particular local twists on the generic themes.

It is very important to notice that in the Serbian version it is not the "peasants" who are the "Riders of the Cultural Apocalypse». If the urban elite, which in Serbia overwhelmingly descended directly from the peasantry, acquired "culture" in the sense of "urbanity", "education", "refinement", and bildung, the "peasants" were supposed to embody "culture" as the repository of the national genius, as Volksgeist. It was thus extremely difficult for the elite to denounce the "peasantry" as lacking culture because that would contradict their traditional position as spokesmen, if not wholesale "inventors" of the Volksgeist embodied by the idealized peasantry.

In a "flat" society based on the ideology of egalitarianism, moreover, elitism that would stray too much from the common run was always suspect, resented and frequently even forcibly supressed. "Even in the most elite institutions ", writes Stojan Cerović, «there was always squatting in some corner a feeling of inauthenticity, the guilt for raising above the people and for emulating the outside world. That's why a powerful 
category of domestic intellectuals loves to invoke the authority of their peasants and to remind everybody to heed that source of wisdom $»^{41}$.

If then the authentic "peasant" is idealized and beyond critique, the odium falls on the inauthentic peasant, the one who abandoned that pristine condition, and lost the volkgeist authenticity without acquiring the "cultural model" of the urbanite cosmopolitan instead. $\mathrm{He}^{42}$ is the peasant-urbanite, the half-breed, the eternal semi-.

Practically all of the Jeremiads on our abysmal cultural conditions abound with images that suggest the state of being somehow half-, or semi-, unfinished, neither here nor there, in transition, in-between, and so on. Božović talks about the "half-world" (polusvet) of the criminal underground, about "suburbs" (predgradje; suggests a zone of neither country nor city proper, thus a liminal, in-between, transitional zone of peasant-urbanites), and about the "twilight" of the metropolis. By mentioning the " fishermen in troubled water" (mutnolovci), he invokes an influential 1938 essay by V. Velmar-Janković on the "Belgrade man" that centers on the phenomenon of "transitionality" (prelaznicarstvo) ${ }^{43}$, and by mentioning «intellectuality, sensibility and morality " (lacking in the mutnolovci), he is invoking the famous essay on Serbian national character by Slobodan Jovanović, which again talks about the "semiintellectual" (poluintelektualac) as a phenomenon linked to our lack of "cultural model".

In one or the other if its guises, it is obvious that the peasant urbanite is the "rider of cultural apocalypse » denounced in the cultural Jeremiads. As an in-between figure, «a hybrid class half-way between village and city ", however, he often comes to stand for a number of other in-between, half-baked, neither-here-nor-there positions : between bildung and Volksgeist, between tradition and modernity, provincialism and cosmopolitanism, between Turkey and Germany, Ottoman Empire and Byzantium, Balkans and Europe, East and West... The Peasant Urbanite thus comes to stand for the whole of the present-day Serbian society rather than just for its uncultured stratum. According to what is perhaps the ur-text of this whole genre of discourse ${ }^{44}$, his is a culture of the "tribe in agony", his world view that of a small town (palanka) seen as some sort of abysmal Purgatory-like twilight zone between the village (tradition) and city (modernity) where Serbs as a whole seem to have gotten stuck for good ${ }^{45}$.

\section{It's Nicer With Culture : Or How a Smiling Mesolithic Figurine Swallowed Oppositional Discourse on Culture}

41 Whatever their position was, however, with Milošević's great turn in August of 1994, the oppositional Jeremiads suddenly found their own agendas and rhetorics appropriated by the very regime they accused of promoting the various « Riders of the Cultural Apocalypse ». "Battle against newly-composed kitsch and chaos in culture ", reports Naša Borba on September 22, 1994, «this is the motto upon which the program and the future endeavors of the Serbian Ministry of Culture are based, announced by the minister of culture Nada Popović-Perišić yesterday at the press conference in Hayat $"$.

42 In the socrealist campaign similar to the one launched 23 years before at the "Congress of Cultural Action" in Kragujevac, the Ministry of Culture mounted an offensive against the « tide of all that is ugly and low, present not only on the radio and television waves, but in everyday life, behavior, speech, morals and the appearance of the city $»^{46}$ 
couched in the rhetoric hardly any different from the rhetoric used by the oppositional Jeremiads. By that move, the regime, through its Ministry of Culture, "colonized" the initiatives of the marginalized oppositionary culture critics and "simulated" their crusade against the very phenomena they strongly associated with the regime itself.

The whole campaign was seen by most oppositional intellectuals as insincere and vacuous, if not outright cynical : «how could she, poor soul », writes M. Glišić about Nada Popović-Perišić, « how could she strangle turbo-folk, when the PMs from her own party are singing to these very tunes in the Serbian Parliament $! »^{47}$ (And we know who that Socialist Party PM was - none other than Bidža of Svilajnac).

The opposition might have protested the insincerity and vacuosness of the campaign, but it couldn't prevent their own rhetorics and steam being stolen by the center which called all the shots, just like the peace initiatives and rhetorics of several parties and groups vehemently opposed to the war from the start were stolen, or appropriated by Milošević's « peace has no alternative » campaign.

The Ministry of Culture next moved from simulating the critique of unculturedness to a wholesale colonization of « what kind of a good thing culture is » by proclaiming 1995 a Year of Culture, and launching an ostentatious PR campaign under the motto: «it's nicer with culture » (Lepše je sa kulturom). The Belgrade affiliate of Saatchi \& Saatchi was paid a large undisclosed sum to produce posters, videos, flags, stickers and badges in the glittery Western marketing style. Thus an endeavor clearly reminiscent of old communist campaigns to "culturally uplift the masses » (kulturno uzdizanje masa) was couched in a form that suggested the opposite - free-market capitalism. "Culture" was treated like any other product to be advertised: "when we work on coffee, some cream, or cookies, it's the same procedure ", a member of the Saatchi \& Saatchi "creative team" explained, «we decided not to talk against kitsch, but for culture ... to try to make culture more interesting ... more familiar to our audience, so that in the market competition between the one and the other (kitsch and culture) we somehow win ».

The campaign covered just about every possible aspect of culture : the emblem of the campaign was a well know Mesolithic figurine from Lepenski vir - therefore culture in this area is thousands of years old (never mind that the Lepenski vir culture had nothing to do with Serbs) ${ }^{48}$; the figure wears a tie - hence the culture of dressing; holds a spoon and knife - hence the culture of eating, that is to say, good manners, and so on. The customary objects and institutions of high culture were heavily represented in their most generic form, but so were the objects of the established pop-culture such as the Levi's jeans, or Coca-Cola. Nor were the emblems of national culture neglected. There is a video clip that shows almost all the icons of national culture in their chronological order, starting with archeological finds of Neolithic, Celtic and Roman times, through the medieval Serbian monasteries, images associated with the $19^{\text {th }}$ century romantic nationalism, and ending with fashionable Paris-based painters. Practically all of the senses of the term "culture" were covered : culture as manners, culture as tolerance, culture as objects of high culture, culture as long standing tradition, culture as expressions of national genius in all of its forms, the High Byzantine embodied in a famous fresco, as well as the populist, Romantic Volksgeist type embodied in the familiar portrait of Vuk Karadžić. 


\section{Conclusion}

In the culture wars of the past several years in Serbia, the various groups that are kept away from the center of power were trying to promote their pretenders to the throne of culture and themselves as a legitimate cultured class entitled to its share of power. They all had to come out and say what kind of a good thing they consider culture to be, and what kind of a bad thing "unculture" (nekultura) is. The center of power, however, didn't need to define anything. The regime just proclaimed that «it's nicer with culture ", something nobody could disagree with. Completely empty of content as it was, that slogan was for this very reason all the more powerful. By avoiding all content, the regime was showing that it is indeed the center, for only the center doesn't need to name itself - everyone knows it is where it should be (tamo gde treba), and that it is doing what should be done (šta treba). In that sense, the Ministry of Culture's slogan was just an extension of the slogan Socialist Party used in the 1992 elections : «tako treba »- a deictic masterpiece if there ever was one. Tako treba and could be translated as "this is how it should be ", or "as it should be ", or "in this way", or simply as «Thus! » Instead of a certain definable goal or quality of action, the utterance brazenly proclaimed that the setting of goals or the quality of action whatever they may be at any moment is dependent on the point of view of the one actor whose identity everyone knew. The phrase also carried with it an echo of a whole genre of expressions widespread in Communist regimes that named the unutterable center of power with precisely such shifters ${ }^{49}$. The slogan immediately became a part of everyday talk easily establishing the intertextual link with the already familiar usage of such shifters during Tito's era : « he phoned where he should » (telefonirao je tamo gde treba), «it was decided where it should (odlučeno je tamo gde treba), « he told whom he should» (rekao je kome treba), and so on. The slogan was a masterpiece of cynicism. It took the whole inchoate experience of that period, with all its misery, trauma and impoverishment and brazenly declared that even all that was As It Should Be. In everyday usage the slogan was commonly given all kinds of ironic twists ranging from «tako nam i treba » (it serves us right) - a rueful recognition of our own responsibility for the miserable condition of our lives, to sardonic counter-slogans, such as those used in the massive protests of the Winter 1996 which counter one by one all the slogans Socialist Party of Serbia used in previous elections ${ }^{50}:$ " with us there's no uncertainty - war " (sa nama nema neizvesnosti - rat) ; « as it should be - sanctions » (tako treba - sankcije) ; «Serbia will not bow down Dayton» (Srbija se saginjati neće - Dejton); « Let's go on - The Hague » (Idemo dalje - Hag). A popular song by the rock band Fish soup capitalized on the fact that "bread" in genitive case (hleba) rhymes with "should" (treba) and produced these lines that were echoed in many less successful versions :

Today, there's no milk, today there's no bread,

So eat shit - perhaps it "Should be That Way"

(Danas nema mleka, danas nema hleba, zato jedi govna- možda tako treba)

All these ironic twists, however, only rebounded on the one who uttered them because no matter how you twisted it, by the very act of uttering the slogan you were still forced to acknowledge that you know very well who was behind it, who the real boss was - which was precisely the effect that the slogan aimed at. 

Ministry said what kind of a good thing culture was, it would have been open to argument. Instead, the slogan pre-emptied all argument, debate and negation, for culture is simply whatever is associated at any given moment with the throne proximity to the throne is the only criterion of value.

51 came to be ridiculed by the cultured opposition in 1995, added yet another moral / cognitive warp to an already benumbingly warped world of Serbia, and it made this latest round of Jeremiads sound a tone of deeper, more desperate anguish than their illustrious ancestors like Slobodan Jovanović, Bogdan Popović, or Vladimir VelmarJanković some sixty to eighty years ago. Even though they talked about the same phenomena, and used the same phrases, these ancestors belonged to a generation of Serbian intelligentsia that essentially was in charge. The Jeremiads of 1994 and 1995 were used and discarded, marginalized and ridiculed, co-opted and silenced, and then finally robbed of their agendas and rhetorics by a chameleon regime wearing the face of Bidža and his likes one day, and that of smiling Mesolithic figurine the other.

\section{NOTES}

1. Arnold (Matthew), «Culture and Anarchy », In Keating (P. J.), ed., Matthew Arnold: Selected Prose, London : Penguin Books, 1982.

2. The reason why turbo-folk was viscerally repugnant to most urban intellectuals in Serbia could be broken into several components. It unselfconsciously and without a trace of irony mixed the rock/pop and the folk tunes and instruments ; it bore the odium of being "newly-composed" (novokomponovan), as opposed to supposedly authentic folk music, and it was the badge of identity for the folknjaks (narodnjaci), the peasant-urbanites "swarming" the cities and threatening the dispossessed cosmopolitan urbanites.

3. See Zivkovic (Marko), "The Turkish Taint: Dealing With the Ottoman Legacy in Serbia", Paper read at AAA Annual Conference, 15-19 November 1995, at Washington, DC (available at http://anthro.spc.uchicago.edu/ mdzivkov/course).

4. Sapir (Edward), «Culture, Genuine and Spurious », The American Journal of Sociology, 29, 1924, p. 402.

5. By the time of this Parliament session, Milošević was widely perceived as being an opportunist rather than a sincere Serbian nationalist.

6. Stanojčić (Vojislav), « TV prenosi iz Skupštine : Pet Vekova SPS-a », Naša Borba, 30/03/95.

7. This attitude belongs to the genre of "rueful self-recognition" (Herzfeld (Michael), Anthropology Through the Looking Glass : Critical Ethnography in the Margins of Europe, Cambridge : Cambridge University Press, 1987), in this case couched in the idiom of self-Orientalization. It reflects perfectly the long-standing Orientalizing (see Bakic-Hayden (Milica), Hayden (Robert), "Orientalist Variations on the Theme "Balkans": Symbolic Geography in Recent Yugoslav Cultural Politics », Slavic Review, 51 (1), 1992 ; Bakic-Hayden (Milica), " Nesting Orientalisms : The Case of Former Yugoslavia », Slavic Review, 54 (4), 1995 ; Zivkovic (Marko), « Representing the Balkans: Symbolic Geography of the South-Eastern Margins of Europe », unpublished 
manuscript, Chicago: Anthropology Department, The University of Chicago, 1990 ; Zivkovic (Marko), «We are Gypsy People Cursed by Fate: Dealing with Balkan Stigma in Serbia and Croatia ", Paper read at The Second Conference of the Association for Balkan Anthropology (ABA), September 4-7, 1997, at Bucharest, Romania) or Balkanizing (Todorova (Maria), Imagining the Balkans, New York / Oxford: Oxford University Press, 1997) discourses about Serbia. A good recent example is offered by D. Rieff : "If anything, it is the Bosnians of Sarajevo, with their fierce devotion to the idea of a multi-confessional, multi-cultural state, rather than the Serbs or the Croats, who are the real Europeans of the former Yugoslavia ", Rieff writes. Modern Turkey, he continues, « has moved on from the Balkans, but the Balkans have not necessarily moved on from the Ottoman legacy (...). The Ottoman empire at its most bloodthirsty and caricatural lives on more completely in the Serb Republic of Bosnia than anywhere in Anatolia ». The Bosnian Serbs do their best to " physically obliterate all the traces of Islamic past from their country. But the more they destroy, the more the Ottomanism they so fear and despise is engrained into their outlooks and their practices » (Rieff (David), « Notes on the Ottoman Legacy Written in a Time of War ", Salmagundi, 1993, pp. 13-14).

8. The use of surrogates appears as a major feature of Milošević's style of ruling, and according to E. Gordy's analysis, offers one way of understanding the tenacity of his "nationalistauthoritarian" regime through a series of seemingly salto mortale changes in ideological rhetorics - from communism to nationalism, from warmongering to peacemongering, and from nationalism to neo-communism again. The "surrogates" provide the regime with a « dependable supply of permutations on the one theme which matters, which is its own continuation in power. By rotating its cast of ideological surrogates through the musical chairs of power, the regime protects itself from its own positions and actions. Rarely speaking or otherwise appearing in public, Slobodan Milošević can rightly claim that he never advocated nationalist or any other positions. In fact, every major political move of his regime has been announced, defended, and removed from the agenda by surrogates" (Gordy (Eric D.), The Destruction of Alternatives: Everyday Life in Nationalist Authoritarianism, unpublished Ph. D. dissertation, Berkeley: Sociology Department, University of California, 1996, p. 121).

9. Ries (Nancy), Russian Talk : Culture and Conversation during Perestroika, Ithaca / London : Cornell University Press, 1997.

10. "Colonization", and "simulation", are terms used by Hankiss (Hankiss (Elemér), "The "Second Society" : Is There an Alternative Social Model Emerging in Contemporary Hungary?", Social Research, 55 (1-2), 1988) to describe « a well-established strategy for dealing with challenges to centralized rule », in the context of Hungary in the late eighties. S. Gal applies these terms in her analysis of Hungarian political rhetoric occasioned by the return of Bartók's body to Budapest in 1988 (Gal (Susan), «Bartók's funeral : representations of Europe in Hungarian political rhetoric », American Ethnologist, 18 (3), 1991).

11. Zivkovic (Marko), «Violent Highlanders and Peaceful Lowlanders: Uses and Abuses of Ethno-Geography in the Balkans from Versailles to Dayton », Replika (Special issue : Ambiguous Identities in the New Europe), 1997.

12. Bakhtin (Mikhail Mikhailovich), The Dialogic Imagination : Four Essays, Austin : University of Texas Press (Slavic series, no. 1), 1994 [1981], pp. 290-293.

13. Politika, 11/03/95.

14. Jovanović (Rade), in NIN, 02/06/95.

15. Trebješanin (Žarko), Duša i politika : psihopatologija nesvakidašnjeg života (Âme et politique : psychopathologie de la vie non-quotidienne), Beograd: Vreme knjige, pp. 105-106. «Moral mimicry » is Cvijić's term - it is similar in meaning to the more modern « identification with the aggressor $»$. 
16. In Stefanović (Dragoljub), «Karakter Srba i ponašanje Pala: Zašto je inat sastavni deo politike» (Caractère des Serbes et l'attitude de Pale: pourquoi l'obstination est une partie intégrante de la politique), Politika, 1994.

17. Popović (Danko), Nespokoji (Turbulences), Beograd : I. P. “Beograd”, 1994, pp. 80-81.

18. When Koljević puts in doubt the extent of "liberation" NIN had achieved by undergoing "the ownership transformation" and thus supposedly becoming "indépendant", he is, of course, accusing it of still being Communist. In this context, it probably means communist because communism often gets blamed for suppressing Serbian national consciousness, and more specifically, the consciousness of the unity of all the Serbs in the former Yugoslavia.

19. I use "bourgeois" here for the Serbian "gradjanski" (pedigre). Both terms exists in Serbian and denote roughly the same thing but their connotations are very different. While buržujski has acquired negative Marxist connotations, gradjanski retains more positive connotations of "civic" or "civil".

20. Djordje Balašević, a composer-singer from Novi Sad whose popularity makes him a "bard" equivalent to say, Bulat Okudzhava in Russia. A line from one of his most popular songs (Ratnik paorskog srca - A Warrior with the Peasant Heart) encapsulates the long standing Romanticization of the Serbian peasant as hard-working and peaceful recently popularized in the novels of Danko Popović and Dobrica Ćosić : «a peasant is not made out to be a soldier, he prefers horses and soil to people ». Balašević is then certainly on Novaković's side but Novaković here casts him as an urbanite who resents "peasantrification" of cities. The contradiction probably disappears if we assume that Balašević referred to peasant-urbanites, the folknjaks that he sociologically defined as a "hybrid class half-way from village to city" in another hugely popular song of his (Narodnjaci - Folknjaks).

21. The only mountain in otherwise completely flat Vojvodina region.

22. Obvious allusion to the Communist allegiances of the highlander newcomers.

23. Novaković (Nikola J), «Premestanje prema rasporedu svetlosti » (Déplacement vers l'éclatement de la lumière), Naša Borba, 24/12/94.

24. I owe this phrase to Professor Raymond Fogelson who suggested it as a logical fourth term in the tripartite classification of types I initially proposed consisting of : 1) The (Šumadija) solid peasant, 2) the cosmopolitan-urbanite, and 3) the peasant-urbanite halfling. At that time, I couldn't find an example of the peasant-cosmopolitan, but I have since realized that in addition to Novaković, such influential writers as Danko Popović and Dobrica ćosić are actually attributing a peculiar kind of "cosmopolitanism" to their idealized peasant characters.

25. Fernandez (James W.), Persuasions and Performances: The Play of Tropes in Culture, Bloomington : Indiana University Press, 1986.

26. Gal (Susan), art.cit.; Gal (Susan), Irvine (Judith T.), "The boundaries of languages and diciplines : How ideologies construct difference », Social Research, 62 (4), 1995.

27. Džadžić (Petar), Homo balcanicus, homo heroicus, 2 vols, Beograd : Prosveta, 1994.

28. A prominent cultural figure in Belgrade, Jerotić gave innumerable well-attended public lectures on literature, psychology, philosophy, and lately theology, in the last twenty or so years. Since he retired from clinical practice, he teaches pastoral psychology at the Belgrade Theological Faculty.

29. Jovanović (Slobodan), "Srpski nacionalni karakter» (Le caractère national serbe), in Jovanović (B.), ur., Karakterologija Srba (Caractérologie des Serbes), Beograd : Naučna knjiga, 1992, p. 230.

30. Greenfeld (Liah), Nationalism: Five Roads to Modernity, Cambridge / London: Harvard University Press, 1992.

31. This happened when writer Svetislav Basara attacked Dobrica Ćosić, Vuk Karadžić and other icons of Serbian cultural identity of the more populist sort. As Ivan Čolović put it, Basara is against the aggressive Serbian nationalism because that nationalism is too folksy and vulgar. 
"Serbian culture and politics, founded on folklore and folk myth making », Čolović summarizes Basara's argument, "should give way to a sacral order founded on the myth of the Medieval Serbian elite, the Slavic being and Byzantine civilization. In other words, Basara is rejecting rightist populism in the name of rightist elitism ». "Those, who like Basara, are disappointed by the return to the epic Kosovo ", Čolović concludes his analysis, " are recommending a return to Byzantium. Nobody, including Basara, suggests a return to the United Nations, but many, and he is among them, rather expect that, as of tomorrow, Serbia will again gain membership in the alternative international organization of the spiritually gigantic and spiritually kindred nations called, as we all know, the Byzantine Commonwealth» (Čolović (Ivan), "Sozercanje ", Naša Borba, 1996). Kosovo, Byzantine Commonwealth and the United Nations are very good labels for the three analytically distinguishable orientations or responses to the predicaments of adopting foreign, Western models (for extended discussion see Zivkovic (Marko), «Inverted Perspective and Serbian Peasants: The Byzantine Revival in Serbia ", Paper read at Negotiating Boundaries: The Past in the Present in South-Eastern Europe, September 6-8, 1998, at Lampeter, Wales).

32. Elias (Norbert), The Civilizing Process : The History of Manners and State Formation and Civilization, Oxford / Cambridge: Blackwell, 1994 ; Elias (Norbert), The Germans: Power Struggles and the Development of Habitus in the Nineteenth and Twentieth Centuries, New York: Columbia University Press, 1996 ; Greenfeld (Liah), op.cit.

33. The conference was organized by the newly formed Democratic Center, a non-party organization led by Dragoljub Mićunović, and was held from 1-2 March of 1995, at the Belgrade Student Cultural Center, formerly a center for alternative and avant-garde but as of recent, firmly under the regime control. The poster announcing the conference featured DeVinci's Mona Lisa with boxing gloves.

34. Musical instruments of Turkish origin.

35. Bourdieu (Pierre), Distinction : A Social Critique of the Judgement of Taste, Cambridge : Harvard University Press, 1984, p. 7.

36. Ibid., p. 469.

37. Thus Dragoljub Mićunović, the leader of the Democratic Center, in his opening speech at the Conference, claims that our society, because of the indeterminacy and fuzziness of its social structure, presents a problem for social scientific understanding:

"The task of social sciences is not at all easy because our society, like the other similar societies, does not lend itself easily to structural analysis. The social structure is illegally and illegitimately formed and doesn't lend itself to the usual criteria. The social strata were formed on the basis of covert privileges and corruption, independently from the social position and status, independently from education and the lifestyle. What then is the social structure like today when one becomes a millionaire or a pauper in a month! With such turbulent and indeterminate social structure the ideological and political spectrum of parties, the differentiation and permanence of their programs, and thus normal parliamentarism is made impossible ».

38. "Those regions of ours" is the best translation I could come up with for the Serbian "na (ovim) našim prostorima ». This is an extremely widespread way of referring to "our country", "here", etc., in a very loose way with accrued connotations of instability of borders, general ambiguity, and the long suffering sense of countless empires and armies which marched through and devastated «these regions of ours".

39. The two uprisings against the Ottomans in 1804 and 1815 that led to autonomy and later independence of Serbia, referred to (most notably by Ranke) as "Serbian Revolution".

40. Personal communication. Latinka Perović was a prominent member of the so-called "Serbian Liberals" who were purged from the leadership of Serbian League of Communists in the early 1970's by Tito. After being ousted, she became a highly respected historian of socialist movements in modern Serbia. 
41. Cerović (Stojan), « Beogradska južna pruga » (La ligne sud de Belgrade), Vreme, 1994. This is where another important notion of what being cultured means could be found. According to that notion, culture is independent of education, even opposed to it. After all, the culturedness of the volk is the supposedly the opposite of the culture of the educated and as interpreted by some of those educated actually superior to it. When Sapir says that an American Indian has better chances at being genuinely cultured than a telephone girl, he is embracing a similar notion of what being cultured means. An example could be found in a review of Momčilo Bošković's book Stranputice - patologija kuluture i karaktera oveka (Strayings : the Pathology of Culture and Human Character) in Politka of March 30. In that case, the word is not culture but « to be spiritually thought out " (biti duhovno promišljen) for which culture could probably be safely substituted. Bošković points out, notes the reviewer, that even an academic "could remain a primitive", while an illiterate person could be a «spiritually thought out individual ... Maybe it is even the case that the former is easier to accomplish".

42. In literature and film this figure is predominantly presented as male in a plot that could be called "reversed Pygmalion". The male is the uncultivated, raw and brutal primitive, who is then cultivated by the ethereal, fragile and cultivated girl from the urban elite (gradjanski sloj) The plot usually takes place at one or another of those upheavals and catastrophes when the new wave of highlanders, barbarians, etc., yet again floods the city and destroys the urban elite (see Zivkovic (Marko), « Tender-hearted Criminals and the Reverse Pygmalion : Narratives of the Balkan Male in Recent Serbian Films ", Paper read at American Anthropological Association Meetings, December 2-6, 1998, at Philadelphia).

43. Velmar-Janković (Vladimir), Pogled s Kalemegdana: Ogled o beogradskom čoveku (Vue de Kalamegdan : regard sur l'homme belgradois), Beograd : Biblioteka grada Beograda, 1992.

44. Konstantinović (Radomir), Filosofija palanke (Small Town Philosophy), Beograd : Nolit, 1991 ( $2^{\text {nd }}$ ed.).

45. Konstantinović sees the spirit of Palanka, underlying the whole of Serbian mentality and culture, as a spirit of « a tribe in agony ». No longer "a tribe" with its a-historical mentality, but a spirit (to use Konstantinovićs cumbersome philosophical jargon of some sort of German provenance) already "infected" with history, already "conscious" of tribe as tribe, thus irreparably distanced from it, the Palanka is a "consciousness rebelling against itself, a consciousness of particularity (individuality) which, on its way towards the freely-open world of the world spirit, as a spirit of infinite possibilities, a spirit of the stylistic multivocality, got stuck, which did not go over from the particularity (or individualism) to the attitude of creative subjectivity, but it is a consciousness which, precisely for that reason, seeks self-cancellation of its own self as cancellation of its own particularity, as a consciousness of the tribe in agony, a tribe which has taken leave of itself and tries to come back» (Konstantinović (Radomir), op.cit., pp. 18-19). This rather unintelligibly written book is one of the most powerful statements, or rather indictments of the national character and its half-bakedness. Much of the lamentation on all kinds of semi- and half- and in-between phenomena, from the peasant urbanite halfling, to the semi-intellectuals Jovanović talks about, could be seen as having their philosophical foundation, or exegesis in the Philosophy of Palanka.

46. Cited by Glišić (Milivoje), « Lepota života » (La beauté de la vie), NIN, 24/03/95.

47. Ibid.

48. I discuss the so-called theories of « Serbs as the Most Ancient People » in Zivkovic (Marko), «Inverted Perspective » (art.cit.).

49. A passage from Vladimir Voinovich's The Life and Extraordinary Adventures of Private Ivan Chonkin, gives a brilliant example. The translation was done by Dale Pesmen who tried to make the untranslatable wordplay understandable in English. Unlike English, the Serbian translation retains the same wordplay that exists in the original Russian.

«To readers from distant galaxies, unfamiliar with our earthly customs, a legitimate question 
might occur - what does the Place Where You Belong mean ? Where You Belong for whom and for what? In this connection, the author offers the following explanation: in the bygone times described by the author, there existed everywhere a certain Institution, which was not so much military as militant ... This Institution acquired the reputation of seeing everything, hearing everything, knowing everything, and, if something was out of line, the Institution would be there in a flash. For this reason people would say, if you are too smart, you'll end up Where You Belong; if you blab too much you'll end up Where You Belong ... One person blabs What he Should, and another, what he Shouldn't. If you blab What you Should, you'll have everything you Should and even a little more. If you blab what you Shouldn't, you'll end up Where You Belong, that is, in the above mentioned Institution. "

50. Naša Borba, 25/11/96, Internet edition.

\section{ABSTRACTS}

In that period, Serbian Jeremiads seemed to reach their "purest" form and became a ubiquitous, if not a dominant genre of social commentary that ranged from everyday talk to discourses of social scientists. Moreover, it is during that period that the Milošević regime makes a 180 degree turn that appropriates, preempts and « colonizes » the rhetorics and initiatives of the opposition Jeremiads by "simulating" their cultural criticism. Moreover, the talk about national character started to focus increasingly on the flip-side of the heroic Dinaric type. Thus Serbian Jeremiads of 1994-1995 can offer a valuable insight into the social tensions and political agendas struggling for supremacy in Milošević's Serbia.

The Jeremiads of 1994 and 1995 were used and discarded, marginalized and ridiculed, co-opted and silenced, and then finally robbed of agendas and rhetorics of the old generation of Serbian intelligentsia by a chameleon regime.

\section{AUTHOR}

\section{MARKO ŽIVKOVIĆ}

M. Živković est professeur d'anthropologie à l'Université de Chicago. 